\title{
Exclusive Breast Feeding in a Bangladesh National Nutrition Program Area: The Case in Bhanga Upazila
}

\author{
Rezaul Karim, Md. Nazrul Islam Khan " and Md. Akhtaruzzaman ${ }^{2}$ \\ Institute of Nutrition and Food Science, University of Dhaka, Dhaka-1000
}

\begin{abstract}
A statistically selected representative sample of 482 households in Bhanga upazila was studied to observe mother's knowledge and practice of the right duration of exclusive breast-feeding in an NNP area. Although a large number of mothers knew the right duration of exclusive breast-feeding, fewer practiced it for their last infant. Apart from some health constratints, lack of knowledge and motivation were the main reasons for early and late introduction of supplementary feeding.

Regular participation in GMP sessions improved mother's knowledge of the right duration of exclusive breast-feeding, and improved knowledge increased practice while higher levels of mother's literacy accelerated the learning. Literate mothers were three times more likely and mothers who participated in GMP sessions regularly were almost three times more likely to know the right duration of exclusive breast-feeding compared to illiterate mothers and mothers who never participated in GMP sessions respectively. Mothers who knew the right duration were about 28 times more likely to practice it compared to the mothers who did not know it.

A strong public awareness campaign aimed at the mothers could better motivate them to participate in GMP sessions more regularly leading to improved knowledge and increased practice of the right duration of exclusive breast-feeding realizing the full potential of NNP.
\end{abstract}

Key words: Exclusive breast feeding, knowledge, practice

Bangladesh Journal of Nutrition. Vol 18-19, December 2005-2006 Institute of Nutrition and Food Science, University of Dhaka-1000, Bangladesh.

a The study was conducted as part of the Field Assignment Course of the fourth year B. Sc. (Hons) students of session 2002-2003 of the Institute of Nutrition and Food Science, University of Dhaka under the supervision of assigned faculty members. The students involved were, in alphabetic order of their last names, Mir Shafi Uddin Ahmed, Md. Nurul Amin, Mst. Yesmin Ara, Prosun Banik, Shoumendra Nath Biswas, Sumon Das, Syeda Kaneez Fatema, Md. Mahfuzul Haque, Md. Imrul Hasan, Chowdhury Tasneem Hasin, Ila Ismail, Md. Mamun Khan, Mahfuza Mubarak, Tania Nushrat, Kapil Kumar Paul, Md. Mezanur Rahman, Sanjib Kumer Saha, Md. Abu Bakr Siddique and Md. Ariful Kabir Sujon. The faculty members involved were Rezaul Karim, Md. Nazrul Islam Khan and M. Akhtaruzzaman.

The authors express their sincere appreciation to Md. Nazrul Islam, Moksed Ali Paramanik, Nadira Khatoon and Umme Salma Monwara Begum of INFS, and Maqbul Bhuiyan of Data management Aid for their invaluable support in data collection and data processing, and to the officials of Bangladesh Extension Education Service (BEES), Bangladesh National Institute of Population Research and Training (NIPORT) and Bangladesh National Nutrition Program (NNP) for providing excellent logistic support during data collection. The study was made possible by a generous grant provided by Nestle Bangladesh Ltd.

\footnotetext{
- Author for correspondence
} 


\section{Introduction}

Exclusive breast-feeding for up to six months of age is a right for infants as well as months recognized by many nations including Bangladesh. It is important because breast milk is the only food necessary for infants for up to six months of age. It is complete in all nutrients for optimum growth, protection and development of the infants. It also has many other advantages. It improves bonding between mothers and children, is stimulating to mothers and children, economical and hygienic. Compared to bottle-fed babies breast-fed babies have much lower chances of catching infection and higher chances of survival. ${ }^{2}$

However, breast milk is not enough beyond six months of age. At this age children's need for energy, protein and several micronutrients grows which breast milk alone cannot meet. To meet the additional needs they need to be given supplementary foods while breast-feeding should still continue for up to two years of age. Continued breast-feeding can delay next pregnancy, which gives the child a better chance of nutritional wellbeing and promote population control.

Lack of awareness of mothers regarding the benefits of breast-feeding, lack of training of mothers regarding the appropriate methods of breast-feeding and misleading campaigns of manufacturers for commercial formula food are considered to be the major obstacles to promote breast-feeding in Bangladesh. It is believed that creating an enabling environment for mothers to breast-feed by empowering them through appropriate training, motivation and family supports can substantially improve breast-feeding practices in the country.

\section{Objectives}

The main objective of the study is to assess the mothers' knowledge and practice of exclusive breast-feeding in an NNP area ${ }^{\mathrm{b}}$. Specifically the study examines the rates of the right knowledge and practice of exclusive breast-feeding and reasons for wrong practice. It also relates the knowledge and practice with socioeconomic and personal characteristics of the mothers.

\section{Materials and Methods}

The Government of Bangladesh through the Ministry of Health and Family Welfare introduced the Bangladesh Integrated Nutrition Program (BINP) initially in six upazilas in the country in 1995 with a view to address the maternal, child and adolescent malnutrition in the country. By 2002 the program covered 61 upazilas. In 2002, after the expiry of BINP, the government introduced the National Nutrition Program (NNP), designed after the lessons learnt from BINP. Initially NNP covered all the BINP upazilas, and by 2005 it covered 105 upazilas in the country.

\footnotetext{
${ }^{b}$ Exclusive breast-feeding is defined by feeding no other food or drink except breast milk for up to six Months of age. Administration of medicines during sickness was allowed.
} 
Although NNP differed from BINP in the details of program administration and management, the basic nutritional interventions and institutional arrangements for service delivery in the two programs were similar. The interventions included, among others, monthly weight monitoring and promotion (WMP) of pregnant women, monthly growth monitoring and promotion (GMP) of under two year old children, daily supplementary feeding of severely malnourished and growth faltered children and low BMI pregnant and postpartum mothers, micronutrient supplementation, home visits and referrals. At the community level the program is implemented by a local Community Nutrition Promoter (CNP) responsible for a Community Nutrition Center (CNC) covering 1000 to 1500 populations under the supervision of contracted $\mathrm{NGOs}^{3}$.

The study was conducted in Bhanga, one of the first phase six BINP upazilas in Faridpur district. Data were collected in April 2005 from a statistically selected representative sample of 528 households by the researchers themselves by personal interview of the mothers using a pre-tested questionnaire. ${ }^{c}$

The households were selected in two stages. Bhanga had 195 CNCs. Assuming that, on the average, 70 households having 6 to 59 months old children would be available in each CNC, seven CNCs were selected systematically in the first stage. In the second stage all the households having 6 to 59 months old children in the selected $\mathrm{CNCs}$ were studied.

\section{Results}

Knowledge and Practice. Valid exclusive breast-feeding data were available from

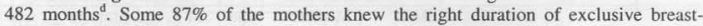
feeding, $10 \%$ of the mothers were not sure about it and $3 \%$ of the mothers knew of wrong duration.

Seventy percent of the mothers practiced exclusive breast-feeding for six months, $17 \%$ of the mothers practiced it for less than six months and $13 \%$ of the mothers practiced it for over 6 months. Among the mothers who knew the right duration, $79 \%$ practiced for six months, $12 \%$ practiced for less than six months and $9 \%$ practiced for over six months (Table 1).

c The sample size was calculated using the formula

Where $\mathrm{P}=n=\frac{Z_{a}^{2} P(1-P)}{d^{2}} \mathrm{f}$.

Where $P=$ anticipated prevalence rate and $Z_{a}=1.96$ at $\alpha=0.05$. Assuming $d=0.05$ and $f=1.25$ the minimum sample size required for the prevalence of $50 \%$ is 480 .

'Some of the women did not participate in the program as they did not live there during the pregnancy or the program was temporarily inoperative due to the changeover of the contracting NGO. The samples were excluded from the study. 
Table 1. Knowledge and Practice of Exclusive Breast-feeding

\begin{tabular}{|l|l|l|l|}
\hline Knowledge & \% of mothers & \multicolumn{2}{|c|}{ Practiced for 6 months } \\
\hline & & $\%$ of mothers & $\begin{array}{l}\text { \% of mothers who knew the right } \\
\text { duration }\end{array}$ \\
\hline Don't know & 10.2 & 0.0 & - \\
\hline Less than 6 months & 2.5 & 16.9 & 12.4 \\
\hline Six months & 86.7 & 69.8 & 78.6 \\
\hline Over 6 months & 0.6 & 13.3 & 9.0 \\
\hline
\end{tabular}

Reasons for Wrong Practice. Lack of milk in breast or sore breast was the major reason for early introduction of supplementary feeding, and family insistence was the major reason for late introduction. Sixty nine percent of all mothers and $78 \%$ of the mothers who knew the right duration of exclusive breast-feeding introduced supplementary feeding early due to lack of milk in breast or sore breast. Some $57 \%$ of all mothers and $76 \%$ of the mothers who knew the right duration introduced it late due to family insistence. However, 'did not feel it necessary' or 'others do it so' were also important reasons for both early and late introduction. Twenty nine percent and $40 \%$ of all mothers and $20 \%$ and $24 \%$ of the mothers who knew the right duration introduced supplementary feeding early and late respectively due to these reasons (Table 2).

Table 2. Reasons for Wrong Practice

\begin{tabular}{|l|l|l|l|l|}
\hline \multicolumn{1}{|c|}{ Reasons } & \multicolumn{2}{|c|}{$\begin{array}{l}\text { Practiced less than 6 months } \\
\text { (\% of mothers) }\end{array}$} & \multicolumn{2}{|c|}{$\begin{array}{l}\text { Practiced more than 6 } \\
\text { months (\% of mothers) }\end{array}$} \\
\hline & $\begin{array}{l}\text { All } \\
\text { mothers }\end{array}$ & $\begin{array}{l}\text { Mothers who } \\
\text { knew right age }\end{array}$ & $\begin{array}{l}\text { All } \\
\text { mothers }\end{array}$ & $\begin{array}{l}\text { Mothers who } \\
\text { knew right age }\end{array}$ \\
\hline $\begin{array}{l}\text { Didn't feel it necessary or others } \\
\text { do it so }\end{array}$ & 28.8 & 19.6 & 39.7 & 24.3 \\
\hline $\begin{array}{l}\text { Lack of milk in breast or sore } \\
\text { breast }\end{array}$ & 68.8 & 78.4 & 3.2 & 0.0 \\
\hline Family insisted & 2.4 & 2.0 & 57.1 & 75.7 \\
\hline
\end{tabular}

Factors Affecting Knowledge and Practice. Bivariate analyses indicate that mother's knowledge and practice of the right duration of exclusive breast-feeding was unrelated to the mean household size and mean farm size. Knowledge was also unrelated to household size, farm size and husbands' occupation but related to mother's own literacy, their husbands' literacy and their participation in GMP. Practice was also unrelated of their own literacy, their husband's literacy, household size, farm size and their husbands' occupation but related to their participation in GMP and their knowledge of the right duration of exclusive breast-feeding (Table 3 ). 
Table 3. Factors Affecting Knowledge and Practice

\begin{tabular}{|c|c|c|c|c|c|c|}
\hline Factors & $\begin{array}{l}\text { Knew } \\
\text { right } \\
\text { duration }\end{array}$ & $\begin{array}{l}\text { Did not } \\
\text { know } \\
\text { right } \\
\text { duration }\end{array}$ & $\begin{array}{l}\text { Sig. p- } \\
\text { value }^{2}\end{array}$ & $\begin{array}{l}\text { Practice } \\
\text { d right } \\
\text { duration }\end{array}$ & $\begin{array}{l}\text { Did not } \\
\text { practice } \\
\text { right } \\
\text { duration }\end{array}$ & $\begin{array}{l}\text { Sig. p- } \\
\text { value }^{2}\end{array}$ \\
\hline $\begin{array}{l}\text { Mean household size (no. } \\
\text { members) }\end{array}$ & 5.6 & 5.5 & 0.756 & 5.6 & 5.5 & 0.433 \\
\hline Mean farm size (decimals) & 83.2 & 49.7 & 0.756 & 85.2 & 64.7 & 0.291 \\
\hline Mothers' literacy & & & 0.008 & & & \\
\hline No schooling (no. women) & 163 & 38 & & 133 & 68 & \\
\hline Class I-V (no. women) & 141 & 16 & & 112 & 45 & \\
\hline $\begin{array}{l}\text { Class VI or more (no. } \\
\text { women) }\end{array}$ & 114 & 10 & & 85 & 39 & \\
\hline Husbands' literacy & & & 0.025 & & & \\
\hline No schooling (no. husbands) & 164 & 36 & & 137 & 63 & \\
\hline Class I-V (no. husbands) & 94 & 13 & & 74 & 33 & \\
\hline $\begin{array}{l}\text { Class VI or more (no. } \\
\text { husbands) }\end{array}$ & 160 & 15 & & 119 & 56 & \\
\hline Household size & & & & 0.473 & & 0.899 \\
\hline Less than 5 members (no. hh) & 121 & 15 & & 91 & 45 & \\
\hline 5-6 members (no. hh) & 195 & 35 & & 159 & 71 & \\
\hline 7 members or more (no. hh) & 102 & 14 & & 80 & 36 & \\
\hline Farm size owned & & & 0.199 & & & 0.037 \\
\hline No land (no. hh) & 166 & 32 & & 131 & 67 & \\
\hline Less than 100 dec. (no. hh) & 171 & 19 & & 142 & 48 & \\
\hline 100 dec. or more (no. hh) & 81 & 13 & & 57 & 37 & \\
\hline Husbands' occupation & & & 0.647 & & & 0.775 \\
\hline Farmer (no. husbands) & 137 & 24 & & 107 & 54 & \\
\hline Laborer (no. husbands) & 113 & 18 & & 92 & 39 & \\
\hline $\begin{array}{l}\text { Business \& others (no. } \\
\text { husbands) }\end{array}$ & 168 & 22 & & 131 & 59 & \\
\hline Participation in NNP GMP & & & 0.004 & & & 0.000 \\
\hline Regular (no. women) & 253 & 26 & & 209 & 70 & \\
\hline Irregular (no. women) & 61 & 10 & & 48 & 23 & \\
\hline Never or rate (no. women) & 104 & 28 & & 73 & 59 & \\
\hline Right duration of EBF & & & & & & 0.000 \\
\hline Know (no. women) & & & & 323 & 95 & \\
\hline Do not know (no. women) & & & & 7 & 57 & \\
\hline
\end{tabular}

a. The means were tested using independent sample t-test and the associations were tested using Chi-square.

Determinants of Knowledge and Practice. A binary logistic model was estimated to find the determinants of the mothers' knowledge and practice of the right duration of exclusive breast-feeding. Mothers' knowledge of the right duration $($ know $=1$, else $=0$ ) and practice of the right duration (practice $=1$. else $=0$ ) were used as dependent variables and the levels of their own literacy, their husbands' literacy, household size, farm size 
and their husbands' occupation were used as independent variables. In the knowledge model the levels of their participation in GMP sessions, and in the practice model the levels of their knowledge of the right duration were also used as independent variables.

The coefficients of the husbands' literacy, household size, farm size and husbands' occupation were not significantly different from zero in the knowledge model, and the coefficients of the mothers' literacy, husbands' literacy, household size, farm size and husbands' occupation were not significantly different from zero in the practice model. However, the coefficient of farm size was large and the variable was retained in the practice model. Finally, the knowledge model was estimated using the mothers' literacy and mothers' participation in GMP sessions, and the practice model was estimated using the farm size and mothers' knowledge of the right duration of exclusive breast-feeding as independent variables.

Table 4. Determinants of the Knowledge and Practice of the Right Duration of Exclusive Breast feeding.

\begin{tabular}{|l|l|l|l|l|l|l|l|l|}
\hline Factors & \multicolumn{3}{|c|}{$\begin{array}{c}\text { Know right duration of exclusive } \\
\text { breast-feeding }\end{array}$} & \multicolumn{3}{c|}{$\begin{array}{c}\text { Practice right duration of exclusive } \\
\text { breast-feeding }\end{array}$} \\
\hline & Odds & \multicolumn{2}{|c|}{$95 \%$ CI } & Sig. & Odds & \multicolumn{2}{|c|}{$95 \%$ CI } & Sig. \\
\hline & ratio & Lower & Upper & p-value & ratio & Lower & Upper & p-value \\
\hline Semiliterate & 2.084 & 1.104 & 3.933 & 0.024 & & & & \\
\hline mothers (class I-V) & & & & & & & & \\
\hline Literate mothers & 2.981 & 1.408 & 6.312 & 0.004 & & & & \\
\hline (class VI or more) & & & & & & & & \\
\hline Medium farm & & & & & 1.328 & 0.801 & 2.201 & 0.271 \\
\hline owners (>100 dec.) & & & & & & & & \\
\hline Large farm owners & & & & & 0.676 & 0.380 & 1.201 & 0.181 \\
\hline $\begin{array}{l}\text { (100 dec. or more) } \\
\text { Irregular }\end{array}$ & & & & & & & & \\
\hline participants in NNP & & & & & & & & \\
\hline Regular participants & 2.838 & 1.569 & 5.132 & 0.001 & & & & \\
\hline in NNP & & & & & & & & \\
\hline $\begin{array}{l}\text { Know right } \\
\text { duration }\end{array}$ & & & & & 27.74 & 12.20 & 63.08 & 0.000 \\
\hline $\begin{array}{l}\text { of exclusive breast- } \\
\text { feeding }\end{array}$ & & & & & & & & \\
\hline Constant & 2.259 & & & 0.001 & 0.120 & & & 0.000 \\
\hline
\end{tabular}

Literate mothers were almost three times more likely to know the right duration of exclusive breast-feeding compared to illiterate mothers, and mothers who participated in GMP sessions regularly were 2.8 times more likely to know it compared to those who never participated. Mothers' literacy had no effect on the practice of the right duration of exclusive breast-feeding. Although not strictly significant mothers coming from medium farm households were about one-third more likely and mothers coming from large farm households were about one-third less likely to practice it compared to those coming from landless households. Mothers who knew the right duration of exclusive breast-feeding 
were almost 28 times more likely to practice it compared to those who did not know it (Table 4).

\section{Discussions}

Knowledge of the right duration of exclusive breast-feeding was widespread among the mothers in the study area. BINP midterm evaluation observed that $27 \%$ of the project mothers knew the right duration of exclusive breast-feeding. In comparison the situation has substantially improved in the present study.

However, practice was not enough and substantial gap existed between knowledge and practice. Unless all mothers know and practice the right duration of exclusive breastfeeding substantial improvement in infant and child nutrition is not expected.

The present study provides some information on how to improve the knowledge and practice of the mothers of the right duration of exclusive breast-feeding. It observed that 'didn't feel it necessary or others do it so', in other words, lack of knowledge and motivation of the right duration of exclusive breast-feeding was an important constraint. for the right practice. It implies that an appropriate information and motivation campaign addressed to the mothers will improve their knowledge and practice of the right duration of exclusive breast-feeding.

Regular participation of the mothers in GMP sessions substantially improved their knowledge and practice while the mothers' literacy accelerated the learning. The finding further supports the need for a strong information and motivation campaign will bring more regular participation of the mothers in GMP sessions leading to improved knowledge and increased adoption of the behavior.

Although not strictly significant, as farm size increased, practice of the right duration of exclusive breast-feeding improved and then declined with the largest farm size. The result has important implication. In rural Bangladesh farm size is a strong indicator of household wealth and food security. It implies that breast-feeding campaigns in Bangladesh should also address household food security targeted to the very poor and landless households to maximize the benefits from the efforts.

\section{References}

1. UNICEF (1998). The State of the World Children, UNICEF, Oxford University Press, New York.

2. Engle P 1999. The Role of Caring Practices and Resources for Care in Child Survival, Growth and Development: South and Southeast Asia. Asian Development Review, Vol. 17, Nos. 1,2.

3. WB 2000. Project Appraisal Document for National Nutrition Project. World Bank, Washington, D.C.

4. INFS (1999). Bangladesh Integrated Nutrition Project Midterm Evaluation. Institute of Nutrition and Food Science, Dhaka University, Dhaka. 